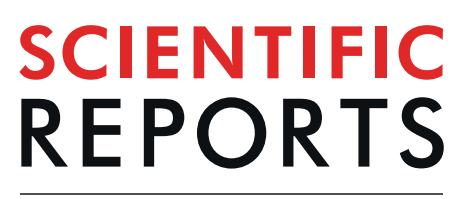

natureresearch

\title{
Efficacy and safety of lavender essential oil (Silexan) capsules among patients suffering from anxiety disorders: A network meta-analysis
}

\author{
Wuan Shuen Yap ${ }^{1}$, Anton V. Dolzhenko (i) ${ }^{1,2}$, Zahraa Jalal ${ }^{3 *}$, Muhammad Abdul Hadi ${ }^{3}{ }^{3}$ \& \\ Tahir Mehmood Khan ${ }^{1,4^{*}}$
}

A systematic review and network-meta analysis (NMA) were performed to estimate significance of the anxiolytic effect of lavender essential oil taken as silexan capsules versus other comparators (i.e., placebo/paroxetine/lorazepam). The outcome of interest was Hamilton Anxiety Scale (HAMA). Weighted mean differences (WMD) were calculated to estimate the treatment effect at the confidence interval of $95 \%$. League tables were generated using treatment effect, for all pairwise comparisons, where $\mathrm{WMD}<0$ favors the column-defining treatment. Five studies were identified with a total of 524 participants receiving treatment with silexan $80 \mathrm{mg}$ and 121 participants taking silexan $160 \mathrm{mg}$. The NMA results indicated that consumption of silexan $160 \mathrm{mg}$ resulted in higher decline of HAMA score [WMD $-1.14(-1.10,3.39)]$ in comparison to silexan $80 \mathrm{mg}$, placebo $[-2.20(-4.64,0.24)]$ and paroxetine $[-1.24(-5.34,2.85)]$. The effect of silexan $80 \mathrm{mg}$ was observed to be same as that of paroxetine. Overall, silexan $160 \mathrm{mg}$ was noticed to be a more efficient treatment giving significant decline in HAMA score across other comparators. However, no improvements in HAMA score was observed for the group receiving lorazepam $0.5 \mathrm{mg}$ when compared to silexan $160 \mathrm{mg}$, silexan $80 \mathrm{mg}$, paroxetine $20 \mathrm{mg}$, and placebo.

Among psychiatric disorders, anxiety disorders are more frequent than others ${ }^{1}$. The global prevalence of anxiety disorders based on the data from 87 studies in 44 countries around the world was estimated to be $7.3 \%{ }^{2}$. The frequency of anxiety in the population differs greatly between countries. The lifetime prevalence of anxiety disorders in United States was reported to be $28.8 \%{ }^{3}, 14.5 \%$ in Europe ${ }^{4}$ and $20 \%$ in Australia ${ }^{5}$. Anxiety disorders have a huge economic impact on society affecting mainly working-age population. Thus, the prevalence of anxiety disorders in United States for the $18-64$ years old population reaches $33.7 \%{ }^{6}$. Anxiety often manifests as a symptom of other psychiatric disorders and also frequently precedes their onset ${ }^{7,8}$. Anxiety disorders are also more comorbid than other mental disorders ${ }^{9}$. Their high comorbidity extended to other psychiatric disorders as well as physical illnesses.

Due to chronic nature of anxiety disorders, patients suffer from them for a long time, sometimes decades. However, therapeutic interventions, such as pharmacotherapy and psychotherapy and their combination, are usually beneficial and improve patient's quality of life often resulting in complete recovery ${ }^{10,11}$. The meta-analysis estimating efficacy of treatments for anxiety disorders suggested that positive effects of pharmacotherapy exceeded those of psychotherapy ${ }^{1}$. Therefore, pharmacotherapy is often critically important in managing patients

\footnotetext{
${ }^{1}$ School of Pharmacy, Monash University Malaysia, Jalan Lagoon Selatan, 47500, Bandar Sunway, Selangor Darul Ehsan, Malaysia. ${ }^{2}$ School of Pharmacy, Curtin Health Innovation Research Institute, Faculty of Health Sciences, Curtin University, GPO Box U1987, Perth, Western Australia, 6845, Australia. ${ }^{3}$ School of Pharmacy, College of Medical and Dental Sciences, Institute of Clinical Sciences, University of Birmingham, Birmingham, B15 2TT, England, UK. ${ }^{4}$ The Institute of Pharmaceutical Sciences (IPS), University of Veterinary \& Animal Sciences (UVAS), Outfall road, Lahore, Pakistan. *email:Z.Jalal@bham.ac.uk; tahir.khan@uvas.edu.pk
} 
with anxiety disorders. However, the chronic character of anxiety disorders and requirements of the long-term treatment set very high safety and compliance standards for the medications and bring phytotherapy as a treatment option ${ }^{12}$.

Phytotherapy has been gaining popularity in the treatment of anxiety ${ }^{13-17}$ with many GABA-modulating medicines of herbal origin undergoing preclinical and clinical investigations ${ }^{18}$. Particular attention has been paid to anxiolytic-like effects of essential oils, among which a lavender essential oil demonstrated the best pharmacological profile ${ }^{19-21}$.

Lavender (Lavandula angustifolia Miller or Lavandula officinalis Chaix) has a long history of traditional use and its essential oil was found to possess a wide range of biological effects ${ }^{22,23}$. Evidence of the effectiveness of the lavender essential oil in the pharmacotherapy of mental disorders led to the development of Silexan, which is a standardized essential oil of $L$. angustifolia flowers prepared by steam distillation ${ }^{24}$. Silexan is approved in Germany for the treatment of restlessness related to anxiety and marketed as LASEA ${ }^{\circledR 25}$.

Silexan was found to contain $36.8 \%$ of linalool and $34.2 \%$ of linalyl acetate ${ }^{26}$. Other components of the lavender essential oil present in substantial quantities include monoterpene alcohol lavandulol, its ester lavandulyl acetate, and bicyclic monoterpenoids borneol, eucalyptol (1,8-cineole) and camphor ${ }^{27,28}$. Linalool also demonstrated anxiolytic properties in several animal models $s^{29,30}$ and possessed stress-relieving effect in humans under the experimental stress ${ }^{31}$. Studies on molecular mechanisms of pharmacological effects of lavender essential oil revealed that its effect on CNS could be attributed to the inhibition of voltage dependent calcium channels ${ }^{26}$. Unlike some other monoterpenes found in the lavender essential oil, linalool and linalyl acetate significantly inhibited voltage dependent calcium channels ${ }^{26}$. In another study, lavender essential oil was demonstrated to possess affinity to the NMDA receptor and SERT ${ }^{28}$. Binding to NMDA receptor was also observed for major constituents of lavender essential oil linalyl acetate and linalool, while only linalool demonstrated significant binding to SERT ${ }^{28}$. Further results of the clinical, randomized, placebo-controlled, double-blind, cross-over study on healthy men using positron emission tomography technology suggested that the anxiolytic effect of lavender essential oil (given as Silexan) could be attributed to the serotonergic system changes, particularly at the $5-\mathrm{HT}_{1 \mathrm{~A}}$ receptor level ${ }^{32}$.

To date, two reviews have been reported in the literature evaluating the efficacy of Silexan in anxietydisorders ${ }^{33,34}$. Review by Kasper ${ }^{33}$ in 2013 was not a systematic review, liable to bias, and the author did not combine results of individual studies using meta-analysis. The systematic review and meta-analysis by Möller et al. ${ }^{34}$ estimated the efficacy of Silexan in sub-threshold anxiety disorders and reported significant reduction in anxiety as measured by HAMA scale. The present systematic review further builds on our existing knowledge on the efficacy of Silexan in the management of anxiety disorders by comparing the efficacy of different strengths of lavender oil using a network meta-analysis technique. This is a unique technique and is considered superior to meta-analysis when direct multiple comparisons between the intervention and control group do not exist in the literature ${ }^{35}$. In addition, our systematic review has evaluated safety of lavender oil as well.

\section{Methods}

A systematic review was performed to identify potential research papers across 8 databases from inception till December 14, 2017. The NMA was performed, in accordance with the recommendations made by the Preferred Reporting Items for Systematic Reviews and Meta-Analyses (PRISMA) ${ }^{36}$, to estimate the overall effectiveness of lavender versus placebo and other medicinal products in anxiety disorders and its adverse effects.

\section{Population intervention comparator and outcomes.}

- Population of interest: Patients with anxiety disorder.

- Intervention: Lavender given orally (capsules).

- Comparators: Placebo or any other medicinal product.

- Outcome: Change in Hamilton Anxiety Scale (HAMA) total score of the patients.

Search strategies. Eight electronic databases including Embase via Ovid, MEDLINE via Ovid, Cochrane, PubMed, AMED, PsycINFO, SCOPUS and EBSCOHost using the following search terms: lavender OR lavandula OR alhucema OR aspic OR lavandin OR lavender essential oil OR lavender oil OR lavandin oil OR aspic oil OR lavender extract OR Silexan OR Lasea OR Kalms Lavender One-A-Day OR CalmAid OR MS 1265 OR linalool OR linalyl acetate AND anxiety.

All the relevant papers were identified and imported to an EndNote file to create a combined library. Duplicate records were removed, where appropriate. Title and abstracts were screened by two authors independently and disagreements were resolved through discussions. Full-texts were downloaded and considered for inclusion based on the inclusion/exclusion criteria described below. Also, we manually reviewed the references of the included studies to identify other relevant studies. Additional details about the studies identified are shown in Fig. 1.

Study selection. The following criteria were used to further align the search with the specific outcomes of interest.

Inclusion criteria.

- All English language studies from inception till December 14, 2017 were considered eligible for inclusion in this systematic review. 


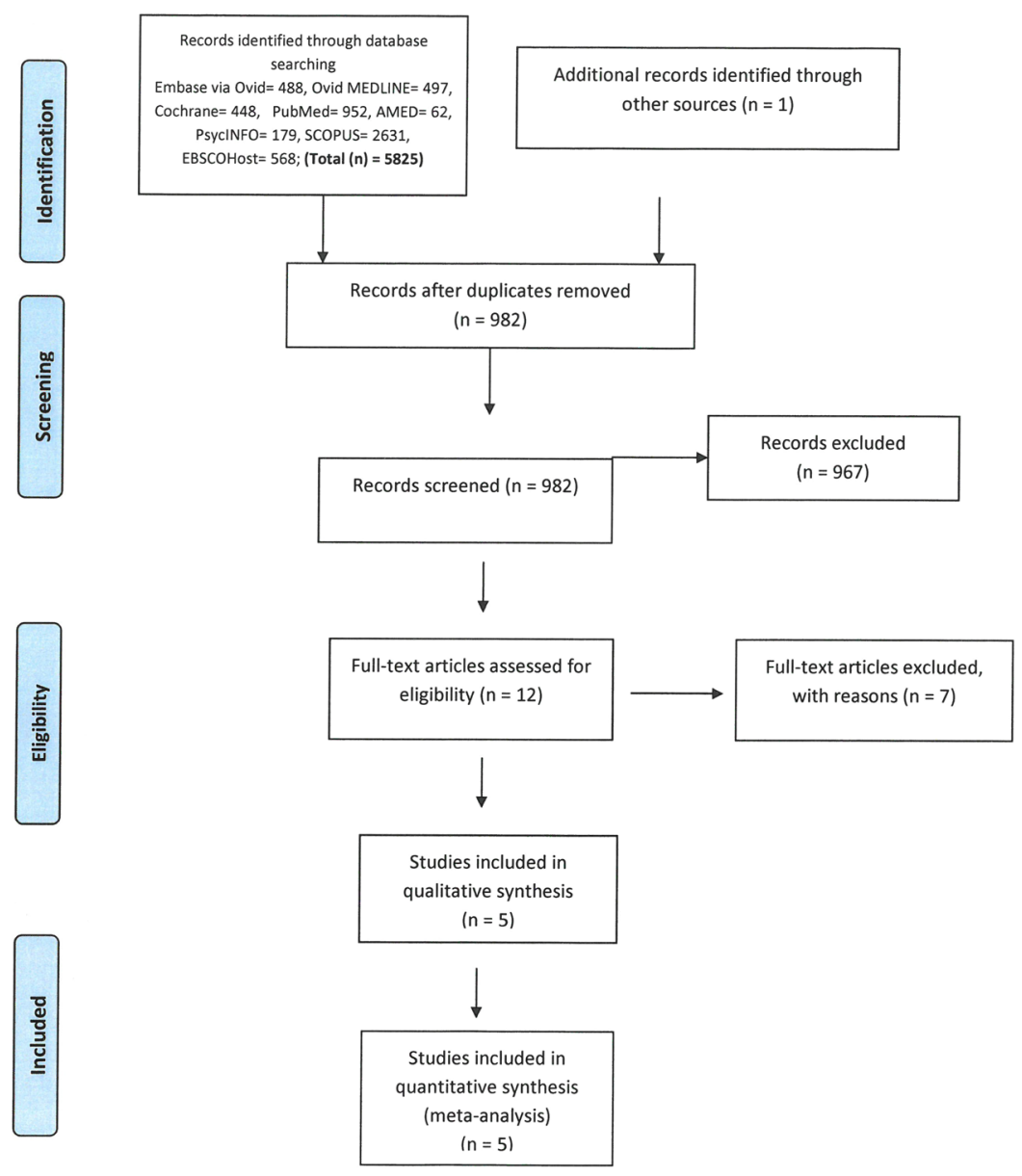

Figure 1. PRISMA flow diagram.

- Only human experimental studies, which are clinical trials comparing the effect of lavender (as a tea, powder or capsule) were considered for potential inclusion in order to assess causal assertions. Comparators considered appropriate were: a placebo, reference/control group, or any other active regimen, which was compared with the lavender formulation given orally.

- The main outcome of interest is the change in Hamilton Anxiety Scale (HAMA) total score of the patients.

Exclusion criteria.

- Systematic reviews, all observational studies, letter to the editors, case reports, case series, personal opinion, qualitative studies, and reviews/communications focusing on individual experience of the use of lavender were excluded.

- In addition, any data that are not published, reports, and thesis were excluded.

- Experimental studies on animals and studies using lavender for aromatherapy were excluded.

\section{Outcome of interest.}

- Primary outcomes: Change in Hamilton Anxiety Scale (HAMA) total score of the patients.

- Secondary outcome: Safety and tolerability of lavender preparations as a medicine.

Data extraction. Data were extracted independently by two review authors (WSY, TMK) and in the case there was a conflict, a third independent assessor AVD assisted in revalidating the data and resolving the conflict. A structured, pilot-tested data collection form was designed to collect data from individual studies. In addition to the data related to the outcomes of interest, data on the number of authors, year of publication, study design, setting and country where the study took place, sample size, patients' mean age and gender, and inclusion criteria and exclusion criteria were also extracted. The results for the outcome measures included in this review were summarized as mean and SD difference from baseline to endpoint in both the intervention and control groups. When not reported, the mean and SD difference were calculated provided sufficient data were available. 


\begin{tabular}{|c|c|c|c|c|c|c|c|c|c|c|c|}
\hline \multirow[b]{2}{*}{ Author } & \multirow[b]{2}{*}{$\begin{array}{l}\text { Recruitment } \\
\text { site }\end{array}$} & \multirow[b]{2}{*}{ Design } & \multicolumn{2}{|l|}{ Study period } & \multicolumn{2}{|c|}{$\begin{array}{l}\text { Sample size (Intervention/ } \\
\text { Control) }\end{array}$} & \multirow[b]{2}{*}{ Intervention(s) } & \multirow[b]{2}{*}{ Comparison(s) } & \multicolumn{3}{|c|}{ Measurement tools } \\
\hline & & & Breakdown & $\begin{array}{l}\text { Total } \\
\text { (for each } \\
\text { participant) }\end{array}$ & Full analysis set & Per-protocol & & & Outcome & Compliance & $\begin{array}{l}\text { Safety and } \\
\text { tolerability }\end{array}$ \\
\hline $\begin{array}{l}\text { Woelk \& } \\
\text { Schlafke } \\
(2009)^{35} \\
\text { Germany }\end{array}$ & $\begin{array}{l}\text { General } \\
\text { practitioner's } \\
\text { clinics }\end{array}$ & $\begin{array}{l}\text { Multi-centre, } \\
\text { double-blind, } \\
\text { randomised } \\
\text { phase III } \\
\text { study }\end{array}$ & $\begin{array}{l}1 \text { week screening } \\
\text { phase, } 6 \text { weeks } \\
\text { treatment } \\
\text { phase, } 2 \text { weeks } \\
\text { discontinuation } \\
\text { phase. }\end{array}$ & 9 weeks & $40 / 37$ & $36 / 33$ & $\begin{array}{l}80 \text { mg Silexan } \\
\text { capsule + } \\
\text { Lorazepam } \\
\text { placebo once } \\
\text { daily during } \\
\text { 6-week treatment } \\
\text { phase, and on } \\
\text { day } 43,45,47,50 \\
\text { and } 53 \text { during the } \\
\text { discontinuation } \\
\text { phase. }\end{array}$ & $\begin{array}{l}0.5 \mathrm{mg} \\
\text { Lorazepam } \\
\text { capsule + } \\
\text { Silexan placebo } \\
\text { once daily } \\
\text { during 6-week } \\
\text { treatment } \\
\text { phase, and on } \\
\text { day 43,45,47,50 } \\
\text { and 53 } \\
\text { during the } \\
\text { discontinuation } \\
\text { phase. }\end{array}$ & $\begin{array}{l}\text { Hamilton } \\
\text { Anxiety } \\
\text { Rating Scale } \\
\text { (HAMA } \\
\text { total score) }\end{array}$ & $\begin{array}{l}\text { Method was } \\
\text { not reported }\end{array}$ & $\begin{array}{l}\text { Adverse events } \\
\text { (AE) reported, } \\
\text { physical } \\
\text { and ECG } \\
\text { examinations, } \\
\text { vital signs, } \\
\text { routine } \\
\text { laboratory } \\
\text { measurements }\end{array}$ \\
\hline $\begin{array}{l}\text { Kasper et al. } \\
(2015)^{38} \\
\text { Germany }\end{array}$ & $\begin{array}{l}17 \text { general } \\
\text { and } \\
\text { psychiatric } \\
\text { practices }\end{array}$ & $\begin{array}{l}\text { Randomized, } \\
\text { double-blind } \\
\text { trial }\end{array}$ & $\begin{array}{l}\text { Single-blind } \\
\text { screening and } \\
\text { wash-out phase of } \\
3-7 \text { days, followed } \\
\text { by } 10 \text { weeks } \\
\text { treatment phase. } \\
\text { Post-baseline } \\
\text { efficacy and safety } \\
\text { assessments } \\
\text { performed every } \\
2 \text { weeks }\end{array}$ & 11 weeks & $86 / 84$ & $73 / 65$ & $\begin{array}{l}80 \mathrm{mg} \text { Silexan } \\
\text { capsule once } \\
\text { daily }\end{array}$ & $\begin{array}{l}\text { Placebo } \\
\text { capsules with } \\
1 / 1000 \text { the } \\
\text { amount of } \\
\text { lavender oil in } \\
\text { Silexan capsules } \\
\text { (to match the } \\
\text { smell of Silexan } \\
\text { capsules) once } \\
\text { daily }\end{array}$ & $\begin{array}{l}\text { Hamilton } \\
\text { Anxiety } \\
\text { Rating Scale } \\
\text { (HAMA } \\
\text { total score) }\end{array}$ & $\begin{array}{l}\text { Compared } \\
\text { the number } \\
\text { of unused } \\
\text { capsules } \\
\text { returned by } \\
\text { the patients to } \\
\text { the expected } \\
\text { number } \\
\text { assuming a } \\
\text { fully protocol } \\
\text { compliant } \\
\text { intake }\end{array}$ & $\begin{array}{l}\text { Adverse events } \\
\text { (AE) reported } \\
\text { spontaneously, } \\
\text { physical } \\
\text { and ECG } \\
\text { examinations, } \\
\text { vital signs, } \\
\text { routine } \\
\text { laboratory } \\
\text { measurements }\end{array}$ \\
\hline $\begin{array}{l}\text { Kasper, } \text { et } \\
\text { al. }(2016)^{39} \\
\text { Germany }\end{array}$ & $\begin{array}{l}35 \\
\text { psychiatric } \\
\text { practices }\end{array}$ & $\begin{array}{l}\text { Double-blind, } \\
\text { randomized, } \\
\text { placebo- } \\
\text { controlled, } \\
\text { parallel-group } \\
\text { multicentre } \\
\text { trial }\end{array}$ & $\begin{array}{l}\text { Screening period } \\
\text { of } 3-7 \text { days, } \\
\text { followed by } 10 \\
\text { weeks treatment } \\
\text { phase. Efficacy and } \\
\text { safety assessments } \\
\text { performed at } 1 \text { and } \\
2 \text { weeks } \pm 2 \text { days, as } \\
\text { well as at } 4,7 \text { and } 10 \\
\text { weeks } \pm 7 \text { days after } \\
\text { baseline }\end{array}$ & 11 weeks & $159 / 156$ & $141 / 128$ & $\begin{array}{l}80 \mathrm{mg} \text { Silexan } \\
\text { capsule once } \\
\text { daily }\end{array}$ & $\begin{array}{l}\text { Placebo } \\
\text { capsules with } \\
1 / 1000 \text { the } \\
\text { amount of } \\
\text { lavender oil in } \\
\text { Silexan capsules } \\
\text { (to match the } \\
\text { smell of Silexan } \\
\text { capsules) once } \\
\text { daily }\end{array}$ & $\begin{array}{l}\text { Hamilton } \\
\text { Anxiety } \\
\text { Rating Scale } \\
\text { (HAMA } \\
\text { total score) }\end{array}$ & $\begin{array}{l}\text { Assessed by } \\
\text { counting } \\
\text { of returned } \\
\text { medication }\end{array}$ & $\begin{array}{l}\text { Adverse events } \\
\text { (AE) reported, } \\
\text { physical } \\
\text { and ECG } \\
\text { examinations, } \\
\text { vital signs, } \\
\text { routine } \\
\text { laboratory } \\
\text { measurements }\end{array}$ \\
\hline $\begin{array}{l}\text { Kasper, } \text { et } \\
\text { al. }(2014)^{37} \\
\text { Germany }\end{array}$ & $\begin{array}{l}57 \\
\text { psychiatric } \\
\text { and general } \\
\text { practices }\end{array}$ & $\begin{array}{l}\text { Randomized, } \\
\text { double-blind, } \\
\text { double- } \\
\text { dummy, } \\
\text { multi-centre } \\
\text { trial with } \\
\text { four parallel } \\
\text { groups }\end{array}$ & $\begin{array}{l}\text { Screening and } \\
\text { wash-out phase } \\
\text { of } 3-7 \text { days, } \\
\text { followed by } 10 \\
\text { weeks treatment } \\
\text { phase. Efficacy and } \\
\text { safety assessments } \\
\text { performed after } \\
2,4,6,8 \text { and } 10 \\
\text { weeks. Treatment } \\
\text { phase is followed } \\
\text { by } 1 \text { week down- } \\
\text { titration phase } \\
\text { for paroxetine } \\
\text { withdrawal }\end{array}$ & 12 weeks & $\begin{array}{l}121(\text { Silexan } \\
160 \mathrm{mg} / \mathrm{d}) / 13 \\
5(\text { Silexan } \\
80 \mathrm{mg} / \mathrm{d}) / 132 \\
\text { (paroxetine)/135 } \\
\text { (placebo) }\end{array}$ & $\begin{array}{l}103(\text { Silexan } \\
160 \mathrm{mg} / \mathrm{d}) / 119 \\
(\text { Silexan } \\
80 \mathrm{mg} / \mathrm{d}) / 114 \\
\text { (paroxetine)/114 } \\
\text { (placebo) }\end{array}$ & $\begin{array}{l}160 \mathrm{mg} \text { Silexan } \\
\text { capsule once } \\
\text { daily; } 80 \mathrm{mg} \\
\text { Silexan capsule } \\
\text { once daily. }\end{array}$ & $\begin{array}{l}20 \mathrm{mg} \\
\text { Paroxetine } \\
\text { capsule; placebo } \\
\text { capsule. }\end{array}$ & $\begin{array}{l}\text { Hamilton } \\
\text { Anxiety } \\
\text { Rating Scale } \\
\text { (HAMA } \\
\text { total score) }\end{array}$ & $\begin{array}{l}\text { Assessed by } \\
\text { medication } \\
\text { counting }\end{array}$ & $\begin{array}{l}\text { Adverse events } \\
\text { (AE) reported } \\
\text { spontaneously, } \\
\text { physical } \\
\text { examinations, } \\
\text { routine } \\
\text { laboratory } \\
\text { measurements. } \\
\text { Withdrawal } \\
\text { symptoms } \\
\text { ascertained by } \\
\text { administering } \\
\text { the Physician } \\
\text { Withdrawal } \\
\text { Checklist } \\
\text { (PWC-20) at the } \\
\text { end of treatment } \\
\text { phase and down- } \\
\text { titration phase. }\end{array}$ \\
\hline $\begin{array}{l}\text { Kasper, et } \\
\text { al. }(2010)^{36} \\
\text { Germany }\end{array}$ & $\begin{array}{l}27 \text { general } \\
\text { and } \\
\text { psychiatric } \\
\text { primary care } \\
\text { centres }\end{array}$ & $\begin{array}{l}\text { Randomized, } \\
\text { double-blind, } \\
\text { placebo } \\
\text { controlled, } \\
\text { multi-centre } \\
\text { trial }\end{array}$ & $\begin{array}{l}\text { Single-blind } \\
\text { placebo screening } \\
\text { and wash-out } \\
\text { phase of 3-7 days, } \\
\text { followed by } 10 \\
\text { weeks treatment } \\
\text { phase. Post-baseline } \\
\text { efficacy and safety } \\
\text { assessments } \\
\text { performed every } \\
2 \text { weeks }\end{array}$ & 12 weeks & $104 / 108$ & $87 / 90$ & $\begin{array}{l}80 \mathrm{mg} \text { Silexan } \\
\text { capsule daily }\end{array}$ & $\begin{array}{l}\text { Placebo } \\
\text { capsules with } \\
1 / 1000 \text { the } \\
\text { amount of } \\
\text { lavender oil in } \\
\text { Silexan capsules } \\
\text { (to match the } \\
\text { smell of Silexan } \\
\text { capsules) once } \\
\text { daily }\end{array}$ & $\begin{array}{l}\text { Hamilton } \\
\text { Anxiety } \\
\text { Rating Scale } \\
\text { (HAMA } \\
\text { total score) }\end{array}$ & $\begin{array}{l}\text { Method was } \\
\text { not reported }\end{array}$ & $\begin{array}{l}\text { Adverse events } \\
\text { (AE) reported, } \\
\text { physical } \\
\text { and ECG } \\
\text { examinations, } \\
\text { vital signs, } \\
\text { routine } \\
\text { laboratory } \\
\text { measurements }\end{array}$ \\
\hline
\end{tabular}

Table 1. Study characteristics.

Data analysis. The risk of bias was assessed individually for each RCT included in this review using Cochrane risk of bias assessment tool ${ }^{37}$. Two authors $(\mathrm{MAH}, \mathrm{ZJ})$ assessed risk of bias independently and disagreements were resolved through discussion.

The network meta-analysis (NMA) was performed using STATA version $14^{\circledR}$. Random effects model was used and weighted mean differences with $95 \%$ confidence interval (CI) were calculated for all continuous outcome measures to compare the effectiveness of the intervention. P-value less than 0.05 was considered statistically significant. Furthermore, in order to generate forest plots for NMA, respective pairwise comparisons for the treatment effect were carried. League tables were created using treatment effect calculated based on weighted mean difference (MD; 95\% CI) for all pairwise comparisons. A league table, a square matrix consisting of all pairwise comparison within a meta-analysis, empowers researcher/reader to directly compare the direction and magnitude of treatment effect, encouraging easier interpretation of results ${ }^{35}$. A negative ( - ) MD indicate decline in the score for the HAMA and SAS scales. 


\begin{tabular}{|c|c|c|c|c|c|c|c|c|c|}
\hline \multirow[b]{2}{*}{ Author } & \multirow[b]{2}{*}{ Respondents } & \multicolumn{3}{|c|}{ Sample size } & \multirow{2}{*}{$\begin{array}{l}\text { Male; } \mathbf{n}(\%) \\
\text { Full Analysis } \\
\text { Set }\end{array}$} & \multicolumn{3}{|c|}{\begin{tabular}{|l|} 
Age (in years) \\
\end{tabular}} & \multirow{2}{*}{$\begin{array}{l}\text { Ethnic } \\
\text { composition } \\
\mathbf{n}(\%)\end{array}$} \\
\hline & & Screened & Randomized & $\begin{array}{l}\text { Completed } \\
\text { study }\end{array}$ & & Range & Median & Mean \pm SD & \\
\hline $\begin{array}{l}\text { Woelk \& } \\
\text { Schlafke } \\
(2009)^{35} \\
\text { Germany }\end{array}$ & $\begin{array}{l}\text { Patients (18-65 years old) with a } \\
\text { primary diagnosis of generalised anxiety } \\
\text { disorder (GAD) according to DSM-IV } \\
\text { (300.02) and outpatient treatment by a } \\
\text { general practitioner. }\end{array}$ & 78 & 77 & 74 & $18(23.4)$ & $21-65$ & N/A & N/A & N/A \\
\hline $\begin{array}{l}\text { Kasper et al. } \\
(2015)^{38} \\
\text { Germany }\end{array}$ & $\begin{array}{l}\text { Male and female patients of any ethnicity } \\
\text { (18 and } 65 \text { years old) with restlessness } \\
\text { and agitation according to the criteria } \\
\text { of ICD-10 diagnostic category R45.1, } \\
\text { Hamilton Anxiety Rating Scale } \\
\text { (HAMA) of at least } 18 \text { points, with } \\
\text { minimum scores of } 2 \text { points for HAMA } \\
\text { items "Tension" and "Insomnia" and } \\
\text { Pittsburgh Sleep Quality Index (PSQI) of } \\
\text { at least } 6 \text { points. }\end{array}$ & 179 & 170 & 148 & $48(28.2)$ & $\begin{array}{l}\text { Silexan } \\
22-67 \\
\text { Placebo } \\
21-67\end{array}$ & $\begin{array}{l}\text { Silexan } \\
49 ; \\
\text { Placebo } \\
48\end{array}$ & N/A & $\begin{array}{l}\text { Caucasian } 169 \\
\text { (99.4); Asian } 1 \\
(0.6)\end{array}$ \\
\hline $\begin{array}{l}\text { Kasper, } \text { et } \\
\text { al. }(2016)^{39} \\
\text { Germany }\end{array}$ & $\begin{array}{l}\text { Male and female patients of any ethnicity } \\
\text { (18 and } 65 \text { years old) with mixed anxiety } \\
\text { and depressive disorder (MADD) } \\
\text { according to the criteria of ICD-10 } \\
\text { criteria and Hamilton Anxiety Rating } \\
\text { Scale (HAMA) of at least } 18 \text { points, with } \\
\text { minimum scores of } 2 \text { points for HAMA } \\
\text { items "Anxious mood" and "Depressed } \\
\text { mood". }\end{array}$ & 362 & 318 & 290 & $97(30.8)$ & N/A & N/A & $\begin{array}{l}\text { Silexan } 47.7 \pm 12.6 \\
\text { Placebo } 47.9 \pm 12.6\end{array}$ & $\begin{array}{l}\text { Caucasian } 316 \\
\text { (99.4); Asian 1 } \\
\text { (0.3); African } \\
1(0.3)\end{array}$ \\
\hline $\begin{array}{l}\text { Kasper, et } \\
\text { al. }(2014)^{37} \\
\text { Germany }\end{array}$ & $\begin{array}{l}\text { Male and female patients of any ethnicity } \\
\text { (18 and } 65 \text { years old) with generalized } \\
\text { anxiety disorder (GAD) according } \\
\text { to DSM-IV-TR and ICD-10 (F41.1), } \\
\text { Hamilton Anxiety Rating Scale (HAMA) } \\
\text { of at least } 18 \text { points, with minimum } \\
\text { scores of } 2 \text { points for HAMA items } \\
\text { "Anxious mood" and "Tension", HAMA } \\
\text { subscore for psychic anxiety of less than } \\
21 \text { points and Covi Anxiety Scale total } \\
\text { score of at least } 9 \text { points }\end{array}$ & 616 & 539 & 450 & $138(26.4)$ & N/A & N/A & $\begin{array}{l}\text { Silexan } 160 \mathrm{mg} / \mathrm{d} \\
47.1 \pm 11.8 ; \text { Silexan } \\
80 \mathrm{mg} / \mathrm{d} 45.7 \pm 11.5 \\
\text { Paroxetine } 45.8 \pm 12.4 \\
\text { Placebo } 44.6 \pm 12.3\end{array}$ & $\begin{array}{l}\text { Caucasian } 537 \\
(99.6) ; \text { Others } \\
(0.4)\end{array}$ \\
\hline $\begin{array}{l}\text { Kasper, } e t \\
\text { al. }(2010)^{36} \\
\text { Germany }\end{array}$ & $\begin{array}{l}\text { Male and female outpatients of any } \\
\text { ethnicity (18 and } 65 \text { years old) suffering } \\
\text { from an anxiety disorder according to } \\
\text { DSM-IV or ICD-10 F41.9, Hamilton } \\
\text { Anxiety Rating Scale (HAMA) of at least } \\
18 \text { points, with minimum scores of } 2 \\
\text { points for HAMA items "Anxious mood" } \\
\text { and "Insomnia" and Pittsburgh Sleep } \\
\text { Quality Index (PSQI) of at least } 5 \text { points. }\end{array}$ & 228 & 216 & 187 & $43(20.2)$ & N/A & N/A & $\begin{array}{l}\text { Silexan } 45.6 \pm 11.4 \\
\text { Placebo } 46.6 \pm 11.3\end{array}$ & N/A \\
\hline
\end{tabular}

Table 2. Participant Characteristics.

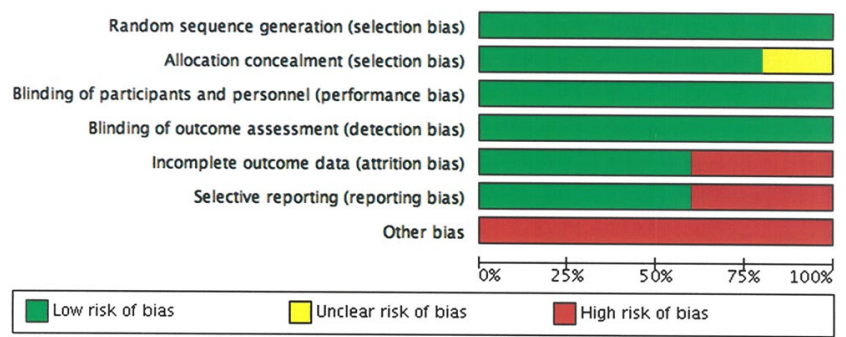

Figure 2. Summary of risk of bias.

\section{Results}

Included studies. Of the 982 studies screened, five randomized control trials were included in this review (Fig. 1).

Characteristics of the studies and type of interventions. To assess the effect of lavender in treating anxiety, interventions included in the 5 studies were placebo, $80 \mathrm{mg} / \mathrm{d}$ silexan, $160 \mathrm{mg} / \mathrm{d}$ silexan, $0.5 \mathrm{mg} / \mathrm{d}$ lorazepam, and $20 \mathrm{mg} / \mathrm{d}$ paroxetine. The study by Woelk \& Schalfke $\mathrm{S}^{38}$ had a treatment phase of 6 weeks whereas the other 4 studies by Kasper et al. ${ }^{39-42}$ had a treatment phase of 10 weeks. All these studies were conducted in Germany. The primary outcome in each study was the change in total score of HAMA. Safety and tolerability of the interventions were assessed by the reporting of adverse events that occurred over the course of the study. Details on study characteristics are available in Table 1.

Although the recruitment criteria for all 5 studies included participants of both genders and of any ethnicity, less than $31 \%$ of participants in each study were male and almost all were Caucasian. Woelk \& Schlafke ${ }^{38}$ 


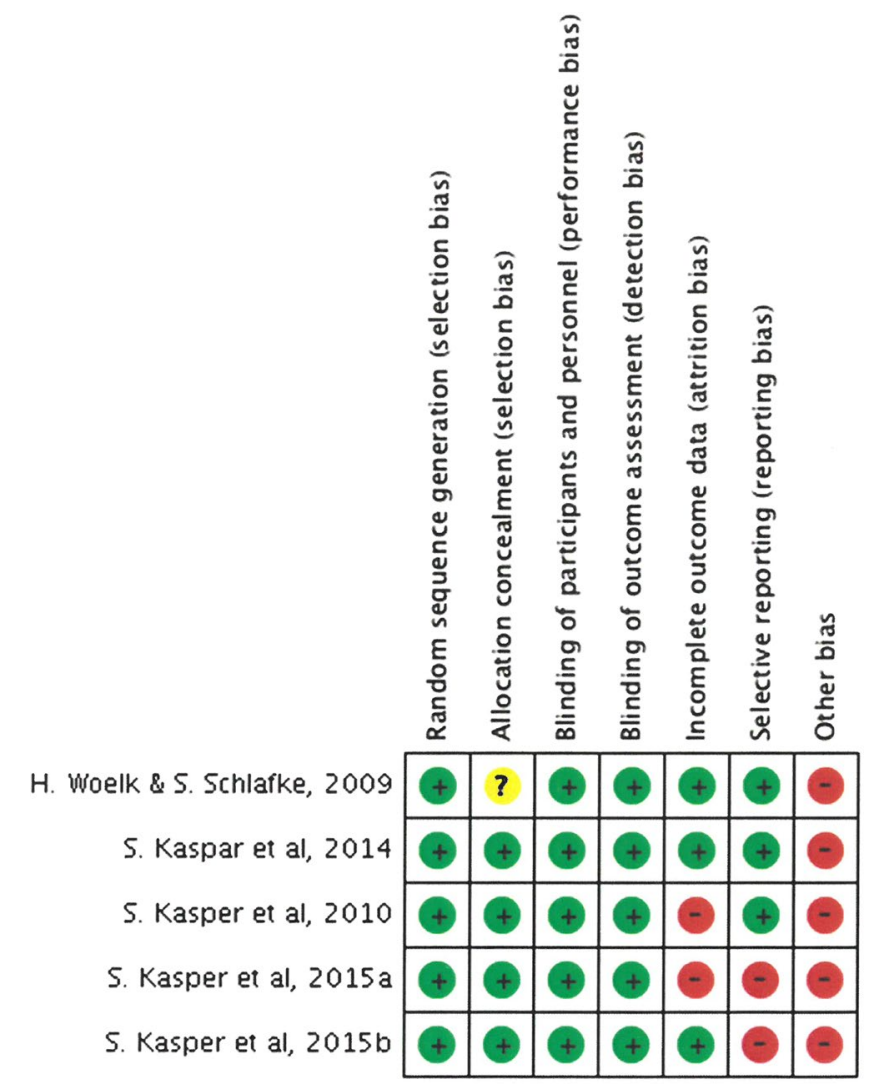

Figure 3. Risk of bias among studies.

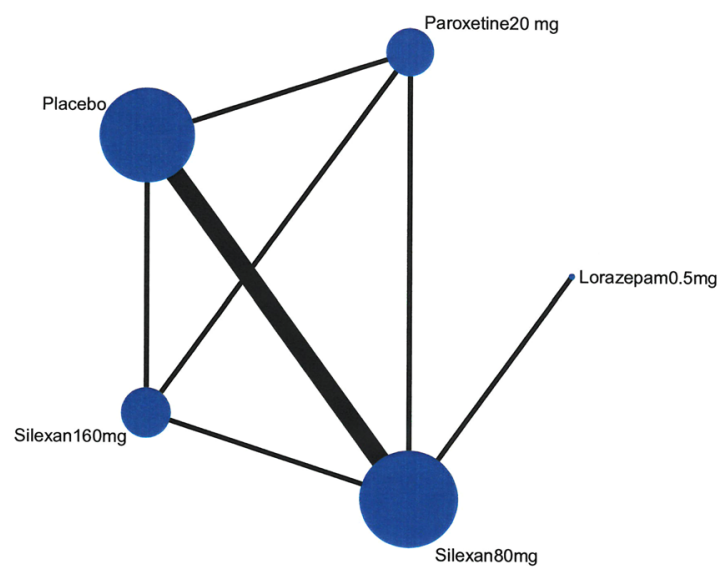

Figure 4. Network Plot.

conducted a multi-center, double-blind, randomised phase III study assessing the comparative effect of $80 \mathrm{mg}$ silexan daily versus $0.5 \mathrm{mg}$ lorazepam daily on a sample size of 78 participants with $23.4 \%$ being male. In this study, 40 participants received silexan $80 \mathrm{mg}$. Kasper et al. ${ }^{39}$ investigated the effect of $80 \mathrm{mg}$ silexan daily against placebo in a randomized, double-blind, multi-center trial with $20.2 \%$ of its 228 participants being male. In this study, 104 participants received treatment with silexan $80 \mathrm{mg}$.

Following that, Kasper et al. ${ }^{40}$ conducted a randomized, double-blind, double-dummy, multi-centre trial with four parallel groups receiving $160 \mathrm{mg}$ silexan daily (121 patients), $80 \mathrm{mg}$ silexan daily (135 patients), $20 \mathrm{mg}$ paroxetine daily, and placebo with $26.4 \%$ of male in the sample size of 616 participants. Subsequently, Kasper et al. in $2015^{41}$ investigated the effect of $80 \mathrm{mg}$ silexan daily and used placebo for the reference group. The study design was a randomized, double-blind trial with $28.2 \%$ of the study's 179 participants being male ${ }^{38}$. In this study, 86 participants were assigned to the silexan $80 \mathrm{mg}$ group. The following year, Kasper et al. published another paper to again investigate the effect of $80 \mathrm{mg}$ silexan daily compared to placebo ${ }^{42}$. In this double-blind, randomized, 


\begin{tabular}{|l|l|l|l|l|}
\hline VS Placebo & $\begin{array}{l}\text { Weighted mean } \\
\text { difference CI 95\% }\end{array}$ & Std. Err & $\mathbf{Z}$ & $\mathbf{p}$ \\
\hline Lorazepam 0.5 mg & $-3.720[-7.435-0.005]$ & 1.895 & -1.96 & 0.050 \\
\hline Paroxetine 20 mg & $-2.763[-4.993-0.533]$ & 1.137 & -2.43 & 0.015 \\
\hline Silexan $160 \mathrm{mg}$ & $-4.963[-7.167-2.759]$ & 1.124 & -4.41 & $<0.001$ \\
\hline Silexan $80 \mathrm{mg}$ & $-3.820[-5.261-2.380]$ & 0.735 & -5.20 & $<0.001$ \\
\hline
\end{tabular}

Table 3. Weighted mean difference of interventions versus placebo. $\mathrm{I}^{2}=0.00 \%$, $\mathrm{Tau}^{2}=0$.

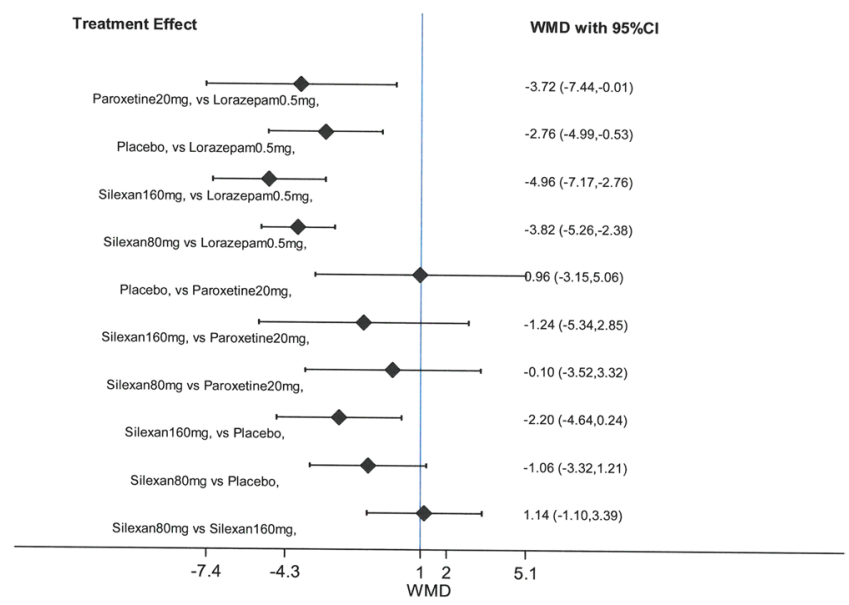

Figure 5. Pairwise comparison of all treatments.

parallel-group multi-centre trial, the sample size was 362 participants and $30.8 \%$ of them were male. The silexan $80 \mathrm{mg}$ group consisted of 159 participants ${ }^{42}$. Further details on participant characteristics are shown in Table 2.

Risk of bias. In general, the overall risk of bias was low for most of the domains for the included studies (Figs. 2 and 3). In particular, risk was low for selection bias, performance bias and detection bias for all the studies. One of the studies has unclear risk of bias for allocation concealment (Figs. 2 and 3). In other biases, studies were deemed to be high risk of bias as they were funded by the manufacturer.

Effect on HAMA score: Primary outcome. To estimate the effect of all interventions on HAMA, five studies were included and a NMA was performed to compare and contrast the effect on the HAMA scale. The network plots demonstrate the organization of all available evidences. The width of the lines represents the number of trials and the size of node represents the sample size (Fig. 4).

Overall analysis. Outcome of interventions versus placebo at HAMA scale. Multivariate analysis was performed to estimate the effect of all the active treatments silexan $160 \mathrm{mg}$, silexan $80 \mathrm{mg}$, lorazepam $0.5 \mathrm{mg}$, and paroxetine $20 \mathrm{mg}$ versus placebo as the reference arm. Results have revealed that effect of placebo was not superior in comparison to silexan. Overall, silexan $160 \mathrm{mg}-4.963[-7.167--2.759], \mathrm{p} \leq 0.001, \mathrm{I}^{2}=0.00 \%$, $\mathrm{Tau}^{2}=0$ ), and silexan $\left.80 \mathrm{mg}-3.820[-5.261--2.380], \mathrm{p} \leq 0.001, \mathrm{I}^{2}=0.00 \%, \mathrm{Tau}^{2}=0\right)$, were noticed to have a significantly higher decline in HAMA score in comparison to placebo. Detailed comparison of all treatment with reference arm is shown in Table 3.

Furthermore, a pairwise analysis was carried out to estimate the comparative effect of all the treatments versus placebo and other interventions. Using the pairwise comparison, a league table was generated to present all possible pairwise comparisons between any two of the five treatments (Fig. 5). Treatment effect, that is, the weighted mean difference of each pairwise comparison was calculated and reported along with the $95 \%$ CI. It was revealed that lorazepam $0.5 \mathrm{mg}$ had no positive effect and did not cause a decline in HAMA score. The treatment with silexan $160 \mathrm{mg}$ was found to be effective in comparison to placebo, paroxetine $20 \mathrm{mg}$, and lorazepam $0.5 \mathrm{mg}$. Overall, the effect of silexan $160 \mathrm{mg}[-1.14(-1.10,3.39)]$, assessed on the basis of declining HAMA score, was superior in comparison to silexan $80 \mathrm{mg}$. In addition, the effect of silexan $80 \mathrm{mg}[-1.06(-3.32,1.21)]$ was observed to be slightly better than that of placebo. The decline in HAMA score was higher for silexan $160 \mathrm{mg}$ in comparison to placebo and paroxetine $20 \mathrm{mg}$. Overall, all interventions including placebo were observed to be more effective in declining HAMA score compared to lorazepam $0.5 \mathrm{mg}$. Details are described in Table 4.

Safety of silexan. In the analyzed 5 studies, adverse events, attributable to silexan use, consisted mainly of gastrointestinal problems such as nausea, eructation or breath odour, and diarrhea. A number of patients also reported having headaches in the 2015 study by Kasper et al. ${ }^{41}$ Nevertheless, the number of patients that experienced these mild adverse events comprised of a small percentage of the sample size. No serious adverse event was found to be linked to the use of silexan. 


\begin{tabular}{|l|l|l|l|l|}
\hline Silexan $80 \mathrm{mg}$ & & & & \\
\hline $1.14(-1.10,3.39)$ & Silexan $160 \mathrm{mg}$ & & & \\
\hline$-1.06(-3.32,1.21)$ & $-2.20(-4.64,0.24)$ & Placebo & & \\
\hline$-0.10(-3.52,3.32)$ & $-1.24(-5.34,2.85)$ & $0.96(-3.15,5.06)$ & Paroxetine $20 \mathrm{mg}$ & \\
\hline$-3.82(-5.26,-2.38)$ & $-4.96(-7.17,-2.76)$ & $-2.76(-4.99,-0.53)$ & $-3.72(-7.44,-0.01)$ & Lorazepam $0.5 \mathrm{mg}$ \\
\hline
\end{tabular}

Table 4. League table for the effect of all interventions on HAMA scale.

\begin{tabular}{|c|c|c|c|c|c|c|c|c|c|c|c|}
\hline \multirow[b]{2}{*}{ Author } & \multirow[b]{2}{*}{ Year } & \multirow[b]{2}{*}{$\begin{array}{l}\text { Intervention/ } \\
\text { Control }\end{array}$} & \multicolumn{9}{|c|}{ Type of Adverse Event (AE) } \\
\hline & & & Nausea & $\begin{array}{l}\text { Eructation/ } \\
\text { breath odour }\end{array}$ & Dyspepsia & Fatigue & Headache & Diarrhoea & Gastritis & \begin{tabular}{|l|} 
Oral \\
discomfort
\end{tabular} & $\begin{array}{l}\text { Naso- } \\
\text { pharyngitis }\end{array}$ \\
\hline \multirow{2}{*}{$\begin{array}{l}\text { Woelk \& } \\
\text { Schlafke }{ }^{35}\end{array}$} & \multirow[b]{2}{*}{2009} & $80 \mathrm{mg} / \mathrm{d}$ Silexan & $4(10.0 \%)$ & $3(7.5 \%)$ & $2(5.0 \%)$ & - & - & - & - & - & - \\
\hline & & $\begin{array}{l}0.5 \mathrm{mg} / \mathrm{d} \\
\text { Lorazepam }\end{array}$ & $1(2.7 \%)$ & - & - & $6(16.2 \%)$ & - & - & - & - & - \\
\hline \multirow{2}{*}{ Kasper et al..$^{38}$} & \multirow{2}{*}{2015} & $80 \mathrm{mg} / \mathrm{d}$ Silexan & - & $6(7.0 \%)$ & - & - & - & $1(1.2 \%)$ & $1(1.2 \%)$ & $1(1.2 \%)$ & - \\
\hline & & Placebo & - & 0 & - & - & - & - & - & - & - \\
\hline \multirow{2}{*}{ Kasper et al..$^{39}$} & \multirow{2}{*}{2016} & $80 \mathrm{mg} / \mathrm{d}$ Silexan & $6(3.8 \%)$ & $32(20.0 \%)$ & - & - & $5(3.1 \%)$ & $3(1.9 \%)$ & - & - & $3(1.9 \%)$ \\
\hline & & Placebo & $2(1.3 \%)$ & 0 & - & - & $11(7.1 \%)$ & $7(4.5 \%)$ & - & - & $8(5.1 \%)$ \\
\hline \multirow{2}{*}{ Kasper et al. ${ }^{36}$} & \multirow{2}{*}{2010} & $80 \mathrm{mg} / \mathrm{d}$ Silexan & - & - & - & - & - & - & - & - & - \\
\hline & & Placebo & - & - & - & - & - & - & - & - & - \\
\hline
\end{tabular}

Table 5. Side-effects reported among the participant consumed placebo and intervention treatment.

Fatigue is a known side effect of lorazepam. In the study conducted by Woelk \& Schlafke ${ }^{38}, 16.2 \%$ of patients receiving treatment with lorazepam had fatigue whereas none in the silexan group experienced fatigue. However, $10.0 \%$ in the silexan group had nausea whereas only $2.7 \%$ had nausea in the lorazepam group.

The actual number and type of total adverse events experienced by the participants in the study conducted by Kasper et al. ${ }^{36,37}$ were not reported in details. Nonetheless, it was noted by Kasper et al. ${ }^{37}$ that the participants receiving treatment with silexan experienced a $3 \%$ increase in risk of gastrointestinal problems compared to those in the placebo group. Further details on adverse events reported in the studies can be found in Table 5.

\section{Discussion}

To date, perhaps it is the first NMA estimating the effect of oral dosage form of lavender i.e. silexan in comparison to placebo, paroxetine and lorazepam on the anxiety score at the HAMA scale. Systematic reviews and meta-analysis have proven to be an effective tool to estimate the clinical efficacy and safety of herbs, and further comparative analysis using network meta-analysis will provide researcher an opportunity to estimate the clinical efficacy and safety of a herb versus various treatments or comparators ${ }^{43}$. Therefore, the current systematic review and NMA will serve as a useful tool in analyzing the use of silexan in clinical settings in an effective manner. The overall analysis revealed that administration of silexan $160 \mathrm{mg}$ produced a higher decline in HAMA score [WMD $-1.14(-1.10,3.39)]$ in comparison to silexan $80 \mathrm{mg}$. The effect of silexan $80 \mathrm{mg}$ was observed to be similar to paroxetine $20 \mathrm{mg}$. Overall, the treatment with silexan $160 \mathrm{mg}$ resulted in more significant decline in the HAMA score across all the comparators and therefore can be considered as the most effective anxiolytic intervention for the included studies. However, it should be noted that the dose of lorazepam used in the included RCT, and subsequently in this NMA, was only $0.5 \mathrm{mg}$ which is the lowest daily dose recommended. Comparative efficacy of silexan with higher dose of lorazepam is not known and needs further research.

The lavender in different forms has been used in cosmetic and therapeutic applications for centuries. These applications were driven by unique scent of lavender essential oil. This essential oil became popular in aromatherapy and its therapeutic effectiveness in this form has been assessed clinically in a number of trials. Particularly, aromatherapy with lavender essential oil was effective in managing preoperative stress and anxiety in various settings significantly decreasing anxiety level compared to placebo ${ }^{44-46}$. However, similar interventions applied after surgery revealed no difference with control group on anxiety level and mental stress $\mathrm{s}^{47,48}$.

The aromatherapy with lavender essential oil improved quality of sleep and reduced level of anxiety in patients with coronary artery disease ${ }^{49}$, significantly reduced anxiety in older patients with acute coronary syndrome ${ }^{50}$ and myocardial infarction ${ }^{51}$. Lower indexes for perceived stress and objective stress were observed in the intensive care unit patients receiving aromatherapy with lavender essential oil ${ }^{52}$. The inhaled lavender essential oil helped to alleviate anxiety in burn patients ${ }^{53}$ and postpartum women ${ }^{54}$.

However, no significant long-term improvements were observed in control of anxiety for patients suffering from cancer receiving aromatherapy treatment with lavender essential oil ${ }^{55}$. No significant difference in the anxiety level was also observed between cancer patients receiving inhalation with lavender essential oil during radiotherapy and the placebo group ${ }^{56}$. Overall, the aromatherapy with lavender as an anxiolytic agent has not been supported by sufficient evidence of therapeutic efficacy ${ }^{57}$. However, our NMA was based on the systemic administration of the lavender essential oil (Silexan) and demonstrated positive evidences for its anxiolytic effect. 
More detailed studies are required for the conclusion regarding other methods for the administration of lavender essential oil, particularly topically or via inhalation.

Strengths and limitations. The exclusion of non-English articles can be one of the limitations of this NMA. This was mainly due to a lack of resources to translate articles written in other languages. There is a slight possibility that some relevant data from these non-English literature, if combined with the current analysis, might change the significance of lavender effects versus other comparators. In addition, all the studies investigating the effect of lavender used its essential oil in form of Silexan capsules. These studies were from Germany and the outcome might be potentially affected by the patients' genetics. To get more comprehensive analysis and conclusions on the effect of lavender and particularly Silexan capsules, similar clinical studies using ethnically more diverse populations are required. The lavender preparations like Silexan capsules might have different results on HAMA scale in other races from different genetic makeup. Moreover, the current analysis estimated only the overall effect of the treatments on HAMA score, the current study was unable to compare the multiple treatments based on the decline in symptoms, severity and relapse of anxiety, which was mainly due to variable reporting of the results across the selected studied for the NMA.

Overall, the other bias was observed across all the five included studies. However, one of the main strength of this NMA is heterogeneity among the one-on-one comparison and pairwise comparison was $0 \%$ which reflects no inconsistencies among the studies. A number of factors including similarities between the study populations across RCTs included in this NMA as all studies were conducted in Germany, similarities in intervention (all in the form of Silexan capsules) and duration of follow-up and use of same tool (HAMA) to assess anxiety in all included studies could explain low heterogeneity observed in NMA.

\section{Conclusion}

Results (through pairwise comparisons) revealed statistically significant effect of silexan $160 \mathrm{mg}$ versus placebo, silexan $80 \mathrm{mg}$ and paroxetine $20 \mathrm{mg}$. In addition, the effect of paroxetine $20 \mathrm{mg}$ was also observed superior than placebo and silexan $80 \mathrm{mg}$. However, silexan consumption has shown some gastrointestinal side effect such as nausea, eructation or breath odor and diarrhea, which were tolerated by the patients recruited in the silexan arm. There is a need of more methodological strong studies to further investigate the effect of silexan among the patients from other regions to get a comprehensive picture about its clinical efficacy and safety.

\section{Data availability}

All materials, data and associated protocols are available to readers without restrictions.

Received: 19 July 2019; Accepted: 13 November 2019;

Published online: 02 December 2019

\section{References}

1. Bandelow, B. \& Michaelis, S. Epidemiology of anxiety disorders in the 21st century. Dialogues in clinical neuroscience 17, 327 (2015).

2. Baxter, A., Scott, K., Vos, T. \& Whiteford, H. Global prevalence of anxiety disorders: a systematic review and meta-regression. Psychological medicine 43, 897-910 (2013).

3. Kessler, R. C. \& Wang, P. S. The descriptive epidemiology of commonly occurring mental disorders in the United States. Annu. Rev. Public Health 29, 115-129 (2008).

4. Alonso, J. \& Lépine, J.-P. Overview of key data from the European Study of the Epidemiology of Mental Disorders (ESEMeD). The Journal of clinical psychiatry (2007).

5. McEvoy, P. M., Grove, R. \& Slade, T. Epidemiology of anxiety disorders in the Australian general population: findings of the 2007 Australian National Survey of Mental Health and Wellbeing. Australian and New Zealand Journal of Psychiatry 45, 957-967 (2011).

6. Kessler, R. C., Petukhova, M., Sampson, N. A., Zaslavsky, A. M. \& Wittchen, H. U. Twelve-month and lifetime prevalence and lifetime morbid risk of anxiety and mood disorders in the United States. International journal of methods in psychiatric research 21, $169-184$ (2012)

7. Kessler, R. C., Ruscio, A. M., Shear, K. \& Wittchen, H.-U. In Behavioral neurobiology of anxiety and its treatment 21-35 (Springer, 2009).

8. Stein, D. J., Scott, K. M., de Jonge, P. \& Kessler, R. C. Epidemiology of anxiety disorders: from surveys to nosology and back. Dialogues in clinical neuroscience 19, 127 (2017).

9. Toft, T. et al. Mental disorders in primary care: prevalence and co-morbidity among disorders. Results from the functional illness in primary care (FIP) study. Psychological medicine 35, 1175-1184 (2005).

10. Baldwin, D. S. et al. Evidence-based pharmacological treatment of anxiety disorders, post-traumatic stress disorder and obsessivecompulsive disorder: a revision of the 2005 guidelines from the British Association for Psychopharmacology. Journal of Psychopharmacology 28, 403-439 (2014).

11. Bandelow, B., Michaelis, S. \& Wedekind, D. Treatment of anxiety disorders. Dialogues in clinical neuroscience 19, 93 (2017).

12. Sarris, J., Panossian, A., Schweitzer, I., Stough, C. \& Scholey, A. Herbal medicine for depression, anxiety and insomnia: a review of psychopharmacology and clinical evidence. European neuropsychopharmacology 21, 841-860 (2011).

13. Ernst, E. Herbal remedies for anxiety-a systematic review of controlled clinical trials. Phytomedicine 13, 205-208 (2006).

14. Sarris, J. Herbal medicines in the treatment of psychiatric disorders: a systematic review. Phytotherapy Research 21, 703-716 (2007).

15. Sarris, J., McIntyre, E. \& Camfield, D. A. Plant-based medicines for anxiety disorders, part 1. CNS drugs 27, 207-219 (2013).

16. Sarris, J., McIntyre, E. \& Camfield, D. A. Plant-based medicines for anxiety disorders, part 2: a review of clinical studies with supporting preclinical evidence. CNS drugs 27, 301-319 (2013).

17. Yeung, K. S., Hernandez, M., Mao, J. J., Haviland, I. \& Gubili, J. Herbal medicine for depression and anxiety: A systematic review with assessment of potential psycho-oncologic relevance. Phytotherapy Research 32, 865-891 (2018).

18. Savage, K., Firth, J., Stough, C. \& Sarris, J. GABA-modulating phytomedicines for anxiety: A systematic review of preclinical and clinical evidence. Phytotherapy Research 32, 3-18 (2018).

19. Edris, A. E. Pharmaceutical and therapeutic potentials of essential oils and their individual volatile constituents: a review. Phytotherapy Research: An International Journal Devoted to Pharmacological and Toxicological Evaluation of Natural Product Derivatives 21, 308-323 (2007). 
20. Dobetsberger, C. \& Buchbauer, G. Actions of essential oils on the central nervous system: An updated review. Flavour and Fragrance Journal 26, 300-316 (2011).

21. de Sousa, D., Hocayen, P., Andrade, L. \& Andreatini, R. A systematic review of the anxiolytic-like effects of essential oils in animal models. Molecules 20, 18620-18660 (2015).

22. Lis-Balchin, M. \& Hart, S. Studies on the mode of action of the essential oil of LavenderLavandula angustifolia P. Miller. Phytotherapy Research: An International Journal Devoted to Pharmacological and Toxicological Evaluation of Natural Product Derivatives 13 , 540-542 (1999).

23. Cavanagh, H. \& Wilkinson, J. Biological activities of lavender essential oil. Phytotherapy Research 16, 301-308 (2002).

24. Kasper, S. et al. Silexan in anxiety disorders: Clinical data and pharmacological background. The world journal of biological psychiatry 19, 412-420 (2018).

25. Lasea. Silexan, https://everything-lavender.com/lasea-lavender-oil-silexan-capsule.html (2018).

26. Schuwald, A. M. et al. Lavender oil-potent anxiolytic properties via modulating voltage dependent calcium channels. PloS one $\mathbf{8}$, e59998 (2013).

27. Da Porto, C., Decorti, D. \& Kikic, I. Flavour compounds of Lavandula angustifolia L. to use in food manufacturing: Comparison of three different extraction methods. Food Chemistry 112, 1072-1078 (2009).

28. López, V., Nielsen, B., Solas, M., Ramírez, M. J. \& Jäger, A. K. Exploring pharmacological mechanisms of lavender (Lavandula angustifolia) essential oil on central nervous system targets. Frontiers in pharmacology 8, 280 (2017).

29. Cline, M. et al. Investigation of the anxiolytic effects of linalool, a lavender extract, in the male Sprague-Dawley rat. AANA journal 76 (2008).

30. Linck, Vd. M. et al. Effects of inhaled Linalool in anxiety, social interaction and aggressive behavior in mice. Phytomedicine 17, 679-683 (2010)

31. Höferl, M., Krist, S. \& Buchbauer, G. Chirality influences the effects of linalool on physiological parameters of stress. Planta medica 72, 1188-1192 (2006).

32. Baldinger, P. et al. Effects of Silexan on the serotonin-1A receptor and microstructure of the human brain: a randomized, placebocontrolled, double-blind, cross-over study with molecular and structural neuroimaging. International Journal of Neuropsychopharmacology 18 (2015).

33. Kasper, S. An orally administered lavandula oil preparation (Silexan) for anxiety disorder and related conditions: an evidence based review. International Journal of Psychiatry in Clinical Practice 17(sup1), 15-22 (2013).

34. Möller, H. J., Volz, H. P., Dienel, A., Schläfke, S. \& Kasper, S. Efficacy of Silexan in subthreshold anxiety: meta-analysis of randomised, placebo-controlled trials. European Archives of Psychiatry and Clinical Neuroscience 269(2), 183-193 (2019).

35. Rouse, B., Chaimani, A. \& Li, T. Network meta-analysis: an introduction for clinicians. Internal and Emergency Medicine 12(1), 103-111 (2017).

36. Moher, D., Liberati, A., Tetzlaff, J. \& Altman, D. G. Preferred reporting items for systematic reviews and meta-analyses: the PRISMA statement. Annals of internal medicine 151, 264-269 (2009).

37. Lundh, A. \& Gøtzsche, P. C. Recommendations by Cochrane Review Groups for assessment of the risk of bias in studies. BMC medical research methodology 8,22 (2008).

38. Woelk, H. \& Schläfke, S. A multi-center, double-blind, randomised study of the Lavender oil preparation Silexan in comparison to Lorazepam for generalized anxiety disorder. Phytomedicine 17, $94-99$ (2010).

39. Kasper, S. et al. Silexan, an orally administered Lavandula oil preparation, is effective in the treatment of 'subsyndromal'anxiety disorder: a randomized, double-blind, placebo controlled trial. International clinical psychopharmacology 25, 277-287 (2010).

40. Kasper, S. et al. Lavender oil preparation Silexan is effective in generalized anxiety disorder-a randomized, double-blind comparison to placebo and paroxetine. International Journal of Neuropsychopharmacology 17, 859-869 (2014).

41. Kasper, S., Anghelescu, I. \& Dienel, A. Efficacy of orally administered Silexan in patients with anxiety-related restlessness and disturbed sleep-A randomized, placebo-controlled trial. European neuropsychopharmacology 25, 1960-1967 (2015).

42. Kasper, S., Volz, H.-P., Dienel, A. \& Schläfke, S. Efficacy of Silexan in mixed anxiety-depression-A randomized, placebo-controlled trial. European neuropsychopharmacology 26, 331-340 (2016).

43. Izzo, A. A., Hoon-Kim, S., Radhakrishnan, R. \& Williamson, E. M. A critical approach to evaluating clinical efficacy, adverse events and drug interactions of herbal remedies. Phytotherapy Research 30, 691-700 (2016).

44. Fayazi, S., Babashahi, M. \& Rezaei, M. The effect of inhalation aromatherapy on anxiety level of the patients in preoperative period. Iranian journal of nursing and midwifery research 16, 278 (2011).

45. Hosseini, S., Heydari, A., Vakili, M., Moghadam, S. \& Tazyky, S. Effect of lavender essence inhalation on the level of anxiety and blood cortisol in candidates for open-heart surgery. Iranian journal of nursing and midwifery research 21, 397 (2016).

46. Wotman, M. et al. The efficacy of lavender aromatherapy in reducing preoperative anxiety in ambulatory surgery patients undergoing procedures in general otolaryngology. Laryngoscope investigative otolaryngology 2, 437-441 (2017).

47. Seifi, Z. et al. The effect of lavender essential oil on anxiety level in patients undergoing coronary artery bypass graft surgery: A double-blinded randomized clinical trial. Iranian journal of nursing and midwifery research 19, 574 (2014).

48. Bikmoradi, A. et al. Effect of inhalation aromatherapy with lavender essential oil on stress and vital signs in patients undergoing coronary artery bypass surgery: A single-blinded randomized clinical trial. Complementary therapies in medicine 23, 331-338 (2015).

49. Karadag, E., Samancioglu, S., Ozden, D. \& Bakir, E. Effects of aromatherapy on sleep quality and anxiety of patients. Nursing in critical care 22, 105-112 (2017).

50. Bahrami, T. et al. Effect of aromatherapy massage on anxiety, depression, and physiologic parameters in older patients with the acute coronary syndrome: A randomized clinical trial. International journal of nursing practice 23, e12601 (2017).

51. Najafi, Z., Taghadosi, M., Sharifi, K., Farrokhian, A. \& Tagharrobi, Z. The effects of inhalation aromatherapy on anxiety in patients with myocardial infarction: a randomized clinical trial. Iranian Red Crescent Medical Journal 16 (2014),

52. Cho, E. H., Lee, M.-Y. \& Hur, M.-H. The effects of aromatherapy on intensive care unit patients' stress and sleep quality: A nonrandomised controlled trial. Evidence-Based Complementary and Alternative Medicine 2017 (2017).

53. Seyyed-Rasooli, A. et al. Comparing the effects of aromatherapy massage and inhalation aromatherapy on anxiety and pain in burn patients: A single-blind randomized clinical trial. Burns 42, 1774-1780 (2016).

54. Kianpour, M., Mansouri, A., Mehrabi, T. \& Asghari, G. Effect of lavender scent inhalation on prevention of stress, anxiety and depression in the postpartum period. Iranian journal of nursing and midwifery research 21, 197 (2016).

55. Soden, K., Vincent, K., Craske, S., Lucas, C. \& Ashley, S. A randomized controlled trial of aromatherapy massage in a hospice setting. Palliative medicine 18, 87-92 (2004).

56. Graham, P., Browne, L., Cox, H. \& Graham, J. Inhalation aromatherapy during radiotherapy: results of a placebo-controlled doubleblind randomized trial. Journal of Clinical Oncology 21, 2372-2376 (2003).

57. Perry, R., Terry, R., Watson, L. \& Ernst, E. Is lavender an anxiolytic drug? A systematic review of randomised clinical trials. Phytomedicine 19, 825-835 (2012). 


\section{Author contributions}

All authors contributed to the preparation of the manuscript for publication as shown below. W.S.Y.- drafted the work, conception, data acquisition, interpretation of data. A.V.D.- data analysis, re-validation of data, Z.J.revised manuscript drafts substantively. M.A.H.-revised manuscript drafts substantively. T.M.K.-conception, data acquisition, interpretation of data, data analysis, revised manuscript drafts substantively.

\section{Competing interests}

The authors declare no competing interests.

\section{Additional information}

Correspondence and requests for materials should be addressed to Z.J. or T.M.K.

Reprints and permissions information is available at www.nature.com/reprints.

Publisher's note Springer Nature remains neutral with regard to jurisdictional claims in published maps and institutional affiliations.

(c) (i) Open Access This article is licensed under a Creative Commons Attribution 4.0 International License, which permits use, sharing, adaptation, distribution and reproduction in any medium or format, as long as you give appropriate credit to the original author(s) and the source, provide a link to the Creative Commons license, and indicate if changes were made. The images or other third party material in this article are included in the article's Creative Commons license, unless indicated otherwise in a credit line to the material. If material is not included in the article's Creative Commons license and your intended use is not permitted by statutory regulation or exceeds the permitted use, you will need to obtain permission directly from the copyright holder. To view a copy of this license, visit http://creativecommons.org/licenses/by/4.0/.

(C) The Author(s) 2019 